\title{
GLOBALISATION OF CULTURAL CIRCUITS. THE CASE OF INTERNATIONAL AWARDS FOR FICTION.
}

\author{
Horea BACANU \\ West University of Timisoara, Romania \\ (C) 2015 Horea Bacanu \\ This is an open access article distributed under the Creative Commons Attribution-NonCommercial-NoDerivs license \\ (http://creativecommons.org/licenses/by-nc-nd/3.0/) \\ DOI: $10.1515 /$ eras-2015-0008
}

\begin{abstract}
In the international circuit of fictional texts from the last fifty years (perhaps even one hundred years, in some cases), several independent international organizations, academic and editorial platforms of critique and debate have been established. They have been organizing international contests, fine authorities of critical appreciation, evaluation and awarding of most prolific authors and most successful fictional texts: novels, short stories, stories or utopian and dystopian fictions. The allotment on cultural corridors, the geographical identification of both author and title dynamics which have been nominated at the most prestigious international awards for fiction demonstrates an increased emergence of several zones where wide international circulation texts were seldom, fifty years ago. In this paper, we suggest a reinterpretation and a comprehension of the political context from the contemporary fiction, by regrouping in one category, the three classical genres (historic novel, social novel, political novel) and also the universal fiction which implies characters and relations of power. Thus, we create a category which is known as ,political fiction”. The increased individualization of this literary macro-genre called „political fiction” is also a creative answer to the high speed of circulation and at the general international amplitude with which contemporary socio-political novels are distributed.
\end{abstract}

Keywords: political fiction, novel, cultural corridor, international awards for fiction, cultural circulation

\section{Theoretical background}

\subsection{Reality construction, cultural consumption, novel, text, new world}

One of the most important perspectives of contemporary social philosophy and social psychology is that of the constructivism, a theory which illustrates the social imaginary's productive ability to generate credible elements and elaborate social fact accomplishment; In the prominent work The Social Construction of Reality, (translated in Romanian by Art Publishing House, 2008), Peter L. Berger and Thomas Luckman state that "The definitions of reality have the capacity of self-accomplishment" (page 173). The statement is as challenging as the whole field of the sociology of knowledge, a matter which is broadly described in this work of the occidental authors.

The French editor of the novel called Submission, written by Michel Houellebecq has come with the suggestion that this title (rapidly becoming renown) be released on the $7^{\text {th }}$ of January 2015, a date of sad remembrance, given the fact that it is the date on which the Charlie Hebdo attack took place. Before being released, the novel which belongs to the political fiction category (as the author himself likes to declare) has been pirated and read by thousands of internauts, with "the frenzy with which international bestsellers are devoured before being released". It was an accurate anticipation of the immediate success the novel has had, shortly after its release, having gone on the first place in the book selling rankings from France, Germany and Italy. The novel explicitly refers to the self-accomplishments of social realities. 
Along the fragment in which the myth of Cassandra is described, the manner in which the reverse of this mythological legend in daily French politics is to be highlighted, as the prophecies of critical French Cassandras (voices of public whistleblowers concerning the menace represented by Muslim immigrants), almost unanimously denied in the media are accomplished in the narrated facts: "For several years, perhaps even decades, Le Monde and all the other centre-left newspapers, videlicet all of them, had systematically denounced "the Cassandras" who were predicting a civil war between the Muslim immigrants and the indigenous populations of Western Europe. As one of my colleagues who teaches Greek literature was explaining to me, this use of Cassandra's myth was, in fact, bizarre...Cassandra was giving the example of constantly accomplished pessimist predictions and analyzing the facts, it appeared that the centre-left journalists were doing nothing but repeating Trojans' recklessness. Historically speaking, such ignorance was nothing new: it could be observed at the intellectuals, the politicians and the journalists in the '30s of last century who were unanimously convinced that Hitler "shall eventually become rational". Perhaps some people who have lived and prospered in a certain social system find it impossible to imagine the point of view of those who, never having something to expect from this system, intend to destroy it, without any remorse whatsoever". (translation from the Romanian version of "Submission", Michael Houellebecq, Humanitas Publishing House, 2015, page 55)

More than the consistency of the fictional reference to the myth of Cassandra, the prediction of this novel's success and its release on the $7^{\text {th }}$ of January 2015 has made possible a peculiar construction of the calamitous terrorist attack on the same date. The attack was the work of two French brothers of Islamic religion and it took place in the editorial office of Charlie Hebdo, a newspaper of satire, whose main theme was the figure of the prophet Mahomed. A practical example for how deep the text referred to the political fiction, far beyond the fiction, to the deeds of a real society. It is perhaps a demonstration of the iron law regarding the self-accomplishment of reality's definitions, at its finest.

Pierre Bourdieu marks the theory of the sociology of culture and art, developing the notion of habitus, that determiné of "the fields of production and reproduction of symbolic goods". The French sociologist and philosopher classifies cultural levels depending on the public of cultural products.

"In the opposition between the two modes of symbolic good production which can only be defined thoroughly as in and through their relations, we must avoid seeing something else than the product of a reductive construction. Inside the same universe, there are always the intermediate cases between the works of art produced by reference to the limited market internal rules and the works of art directly commanded through an intuitive, scientifically informed representation of the expectations coming from the most general public: thus, in order to point out only a few landmarks, we have the avant-garde works, reserved to a bunch of equals, the avant-garde works that are on the verge of becoming famous or are already appreciated by the group of producers, "bourgeois works of art", reserved to unintellectual factions of the dominant class and frequently appreciated by the most official instances of legitimization (academies) and finally, the medium-level works of art, inside whom we might still distinguish, according to the position held in the official ranking of "the target public" the high culture (where works which have been awarded great literary awards can be found), the culture of imitation with the sum of messages mainly addressed to middle class and namely ascending factions of this class (for example, works of literary or scientifical popularization) and the mass culture, videlicet the sum of some works, and if I may say so, omnibus." (translation from the Romanian version of "The Economy of Symbolic Goods", page 66) 
Thus, Pierre Bourdieu defines the high culture in a text that was written right in the first period of reference of the present paper (1985), bringing one of the most proficient tools in the analysis of literature's cultural circulation, defining categories of narrow and wide circulation, categories to which the fictional products make reference to. Differences of evolution in the literary circuits of the latest years are clearly demonstrated by the empirical data we have collected. They are illustrating an increasingly important dynamics of winning authors, compared to the first phase of the period of reference for the contemporary fictional literature (the ' 80 s as against the whole period of 1980-2015).

The novel, as a result of the socially modeled artistic imaginary is one of the main cultural habits and contemporary instruments of dominance and communication, an instrument which produces credible social facts.

The internationally awarded novel is no longer a large scale by-product especially designed for the specific of a massified public, but an increasingly symmetric product which is equally addressed to critics, professionals of the artistic market, creators and qualified people, as well as the general public consisting of readers belonging to all the categories.

An enumeration of the most important communicational habitus which ease the contemporary cultural circulation, must definitely contain: the online multimedia content, new media online, television and written texts. The latter, the written text should be regarded as a cultural information carrier which varies according to at least two characteristics (which are not found at the other communicational habitus):

- It is multi - significant: it has a high degree of composition of the social meanings implied in discursivity and subjectively decipherable in a differentiated manner, by the various publics;

- It is authentic, not only by referring to values and faiths but also by perceiving the relation with the reader, establishing inside the intersubjectivity a "new world" of the fictional speech which is at least equally meaningful as the other worlds of the globalised society.

\subsection{Globalisation, circulation of ideas, salient fictional realities, large public}

For centuries, the fiction has been offering socially meaningful speeches, productive and inventive speeches as compared to larger and larger publics, and the globalization of the society has emphasized this dynamics. The circulation of ideas in the form of contemporary fictions (regardless of the genre) is probably one of the most direct forms of global circulation (larger and more intense than the circulation of money, goods, people), although, at a first sight, we might be tented to believe that the forms of free circulation of money, goods and even people could have a priority.

Having its inexhaustible source in the large circulation of ideas, a process that is nowadays more dynamic than ever, the globalised society is the place of encounter of salient fictional realities that we could not foresee 50, 100 or maybe more years ago.

Two examples can perfectly illustrate these ideas:

- The satanic verses, a novel written by Salman Rushdie which fully corresponds to the universe of political fictions. It generated a wave of accusations from behalf of the religious Islamic leaders, culminating with the death conviction of the author, by the ayatollah Khomeini.

- The novel Submission, by Michel Houellebecq. The novel's release date coincided with the terrorist attack of Charlie Hebdo magazine.

- Without appealing to simple self-accomplishment prophecy mechanisms, the salient fictional realities found in contemporary political texts imply: 
- A positioning in the close proximity of the reader by post-modern intersubjectivity manners, methods of communicational design of authenticity;

- Actors, scenes, performing, publics and political relations, videlicet, a discursively engaged political dramaturgy;

- A mosaic of realistic and surrealistic actions which denote a political intentionality and finality with creative auspices, this being the ideological bearing of political fictions.

Between several levels and layers of the fictional forms, over the course of time, sociopolitical meanings have been identified in three genres of the contemporary, modern novel: the historic novel, the social novel, the politic novel.

Without insisting on this conventional framing carried out by contemporary cultural studies, we shall suggest a reinterpretation and a further comprehension of how the political context has been positioned in the contemporary fiction, regrouping, in only one category, the three previously enumerated genres. Thus, in the category "Political fiction", all the meanings and components of the three mentioned novel genres can be found. The increased individualization of this literary macro-genre called "political fiction" is also a creative answer at the high speed of circulation and at the general international amplitude with which contemporary sociopolitical novels are distributed.

"The political fiction" involves the author and the readers and it implies a complex of highly-organised and intermediated through large chains of editors and booksellers distribution conditions. It also implies critics, referents, bloggers, online platforms, specialized readers, all these being involved in power relations and putting at stake meaningful and imaginative resources from the mentioned texts. Thereby, they are conceiving a hermeneutics of the contemporary political text and they are engaging in a mechanism of power throughout the international cultural circuit of the "general public".

In the international circuit of fictional texts from the last fifty years (in some cases perhaps one hundred years) several independent international organizations, as well as academic platforms and editorials of critics and debate have become known. They have been organizing international contests with awards, fine authorities of critical appreciation and awarding for the most prolific writers and the most successful fictional texts, whether we are talking about novels, short stories, stories or utopian and dystopian fictions.

In the contemporary period, literary awards may actually represent a context of social recognition regarding the circulation of these papers, they are addressed to "the general public" which appreciates them, consequently generating a number of copies which were impossible to reach before and translated versions on all continents. The organizers of literary awards elaborate rankings of sold copies and methodically analyze reviews published in the most important publications. Hence, they are factors of power in the cultural circuits.

Literary awards for contemporary fictions have the role of recognizing the success and the critical impact obtained by both authors and titles. These awards play a decisive role in promoting authors (and their papers) towards international publics and towards important cultural zones on all the continents. The international literary awards also play an intermediary and multiplier role, generating waves of copies and areas of recurrent distribution of fictional texts. 


\subsection{Macro-circuits of book distribution - general publics and political fictions}

Before proceeding with the phase of acknowledgement and analysis of contemporary socio-political texts, before practicing the qualitative analysis of political fictions, we ought to quantitatively categorize the most important authors and titles which are distributed intermediately and multiply throughout the circuit of literary awards. From the international circuits of awards, to the regional ones and up to the most important dozens of high value international awards, the circulation of fictional texts is increasing and densifying each year, culminating with hundreds of names and titles of authors nominated amongst finalists and winners of these awards. Other circuits of local awarding are added to the 500 national awards for literature.

Nowadays, winning a high international literature award means guaranteed sales of millions of copies (in digital and printed format), something that 50 or 100 years ago was very seldom. A good classification of these awarding circuits shall imply:

- Defining the cultural corridors of authors' origin and book distribution;

- An inventory of cultural corridors having high dynamics in book circulation, an important issue for the future selection of texts belonging to the mentioned category (political fictions);

- An evaluation of author diversity with reference to authors having a high rate of distribution;

\section{Empirical study}

\subsection{The circuit of literary awards: more than 500 important awards}

Graph 1 illustrates categories of national, regional and international awards from the annual circuit of literary awards. Between the 516 inventoried literature awards, 30 international awards can be grouped. These 30 awards are characterized by:

- Major cultural importance;

- High financial value of awards;

- The fewest conditionings of authors' origin areas (no conditionings are also possible);

- High influence for the most important cycles of publishing - number of copies sales.

The 64 regional awards are characterized by:

- High relevance for the market of writers, cultural intermediates and readers of a specific supranational foreign language;

- Are dedicated to languages such as: the Arab, the Chinese, the Hebrew, the Portuguese, the Spanish;

- Certain regional awards have become international (especially those for the English, Spanish, Portuguese and Arab language) due to the high financial value of the awards which has interested the cultural intermediates.

The 422 national awards:

- Only have an impact at national level;

- Are intermediary phases for the regional or international level of literary awards;

- Are bases of selection for cultural intermediates (publishing houses, libraries, reviewers, critics). 
Graph 1: Annual statistics of literature awards: national, regional and international awards

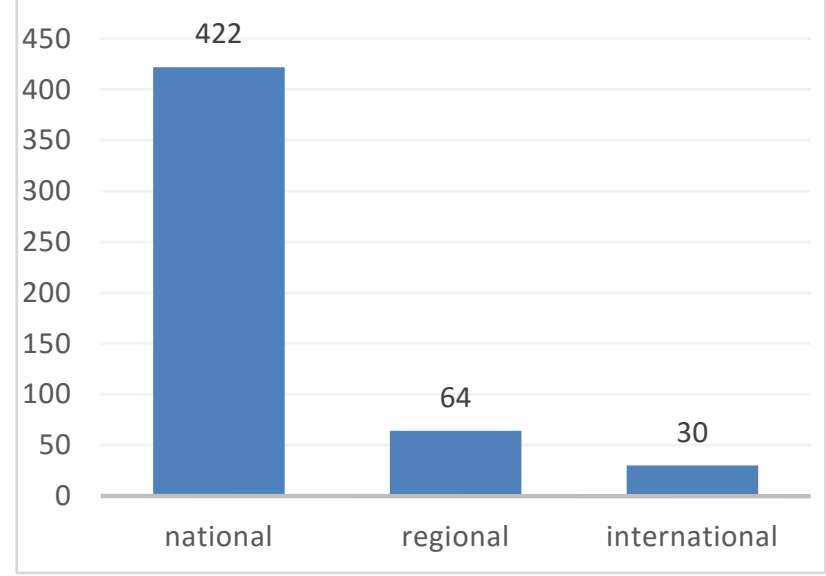

\subsection{A macro-universe of literature emergence: national and international awards}

The national awards cover more than $80 \%$ of the cultural circuit of literary awards (422 out of 516). A quarter of the market of national awards originates in the United States of America (110 out of 422). The other quarter originates in Canada and France (according to Table 2, although authors and French titles do not possess an important share in the circuits of the 30 major international awards, according to Table 1). A part of the most important awards for English and Spanish language have converted from national or regional to international level (due to higher amplitude on markets and cultural intermediates' interest for these markets).

Graph 2: Country statistics concerning literature awards

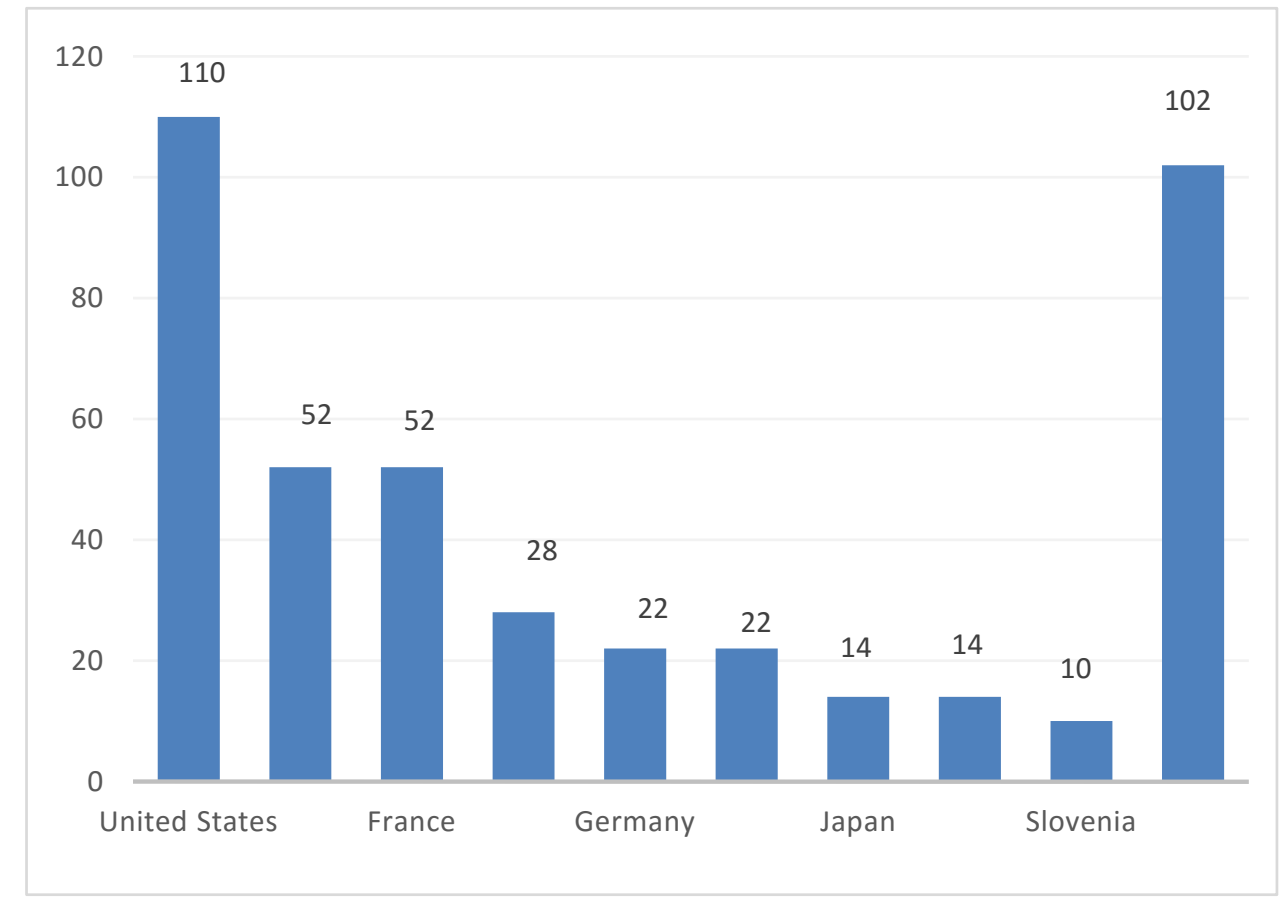


Table 1: List of international awards for literature, award value and organizer's state of origin

\begin{tabular}{|c|c|c|}
\hline Award & Award value (USD) & Organizer's country of origin \\
\hline Nobel Prize in Literature & 1100000 & Sweden \\
\hline Premio Planeta de Novela & 660000 & Spain \\
\hline São Paulo Prize for Literature & 200000 & Brazil \\
\hline Sheikh Zayed Book Award & 200000 & United Arab Emirates \\
\hline Alfaguara Prize & 175000 & Spain \\
\hline FIL Award (fost Juan Rulfo Prize) Romance Lan. & 150000 & Spain \\
\hline Miguel de Cervantes Prize & 150000 & Spain \\
\hline Sonning Prize & 150000 & Denmark \\
\hline Premio de Novela Fernando Lara & 135000 & Spain \\
\hline Camões Prize & 110000 & Brazil / Portugal \\
\hline Rómulo Gallegos Prize & 110000 & Venezuela \\
\hline The International IMPAC Dublin Literary Award & 110000 & Ireland \\
\hline Sami Rohr Prize for Jewish Literature & 100000 & Israel \\
\hline The Man Booker International Prize & 90000 & Great Britain \\
\hline The Man Booker Prize & 75000 & Great Britain \\
\hline Neustadt International Prize for Literature & 50000 & United States of America \\
\hline Jan Michalski Swiss Prize for Literature & 50000 & Switzerland \\
\hline Al Owais Award & 50000 & United Arab Emirates \\
\hline Costa (formerly Whitebread) Book Award & 45000 & Great Britain \\
\hline Women's Prize for Fiction & 45000 & Great Britain \\
\hline German Book Prize & 30000 & Germany \\
\hline Thomas Head Raddall Award & 25000 & Canada \\
\hline Victorian Premier's Literary Awards & 25000 & Australia \\
\hline Solzhenitsyn Prize & 25000 & Russia \\
\hline Dayton Literary Peace Prize & 10000 & United States of America \\
\hline Franz Kafka Prize & 10000 & Czech Republic \\
\hline Jerusalem Prize & 10000 & Israel \\
\hline International Prize for Arabic Fiction & 10000 & United Arab Emirates \\
\hline Independent Foreign Fiction Prize & 7500 & Great Britain \\
\hline Prix Goncourt & - & France \\
\hline
\end{tabular}

\subsection{The circuit of literary awards: more than 500 important awards}

Table 2 quantitatively describes the 11 macro - regional cultural corridors. These corridors are geographical macro - zones which subtend groups of countries from the major continental or subcontinental borders, characterized by the use of a high circulation and high influence language, a common cultural history (sometimes only influenced by one of the corridor's influent countries), a common cultural, religious and political capital, strong regional circuits of the cultural, economic, technological and political circulation.

Table 2: List of macro - regional cultural corridors

\begin{tabular}{lcccc}
\hline \multicolumn{1}{c}{ Cultural corridor } & Dominant language & \multicolumn{3}{c}{$\begin{array}{c}\text { Number Percentage of Percentage of } \\
\text { of } \\
\text { the world's } \\
\text { the world's } \\
\text { surface }\end{array}$} \\
\hline North-american & English / French & 2 & 5 & 15 \\
Central and South-american & Spanish & 35 & 10 & 16 \\
Australian and New Zealand & English & 11 & 1 & 6 \\
Oriental (pen)insular and Indian & National & 18 & 32 & 7 \\
Middle East & National & 20 & 5 & 5 \\
Far East & National / Russian / Chinese & 11 & 24 & 14 \\
Central and East European & National & 16 & 6 & 14 \\
South-european & National & 13 & 3 & 1 \\
Western and North-european & National & 16 & 4 & 2 \\
Sub-Saharian Africa & National / English / French / Portuguese & 47 & 7 & 10 \\
North-African & National / English / French / Portuguese & 11 & 3 & 9 \\
\hline
\end{tabular}


Graph 3 illustrates the emergence of the 30 international literature awards. Out of these, more than one half (18) are given by organizers coming from European countries. As far as the international awards coming from the Middle East are concerned, we can observe an emphasized tendency of establishment. In the Far East, the (Pen)insular East and the Indian East, as well as in the North African and Sub-Saharian Africa, there are no important international awards (corridors grouping 80 countries and $70 \%$ of world's population).

Graph 3: Distribution in cultural columns for the origin of the 30 international literature awards

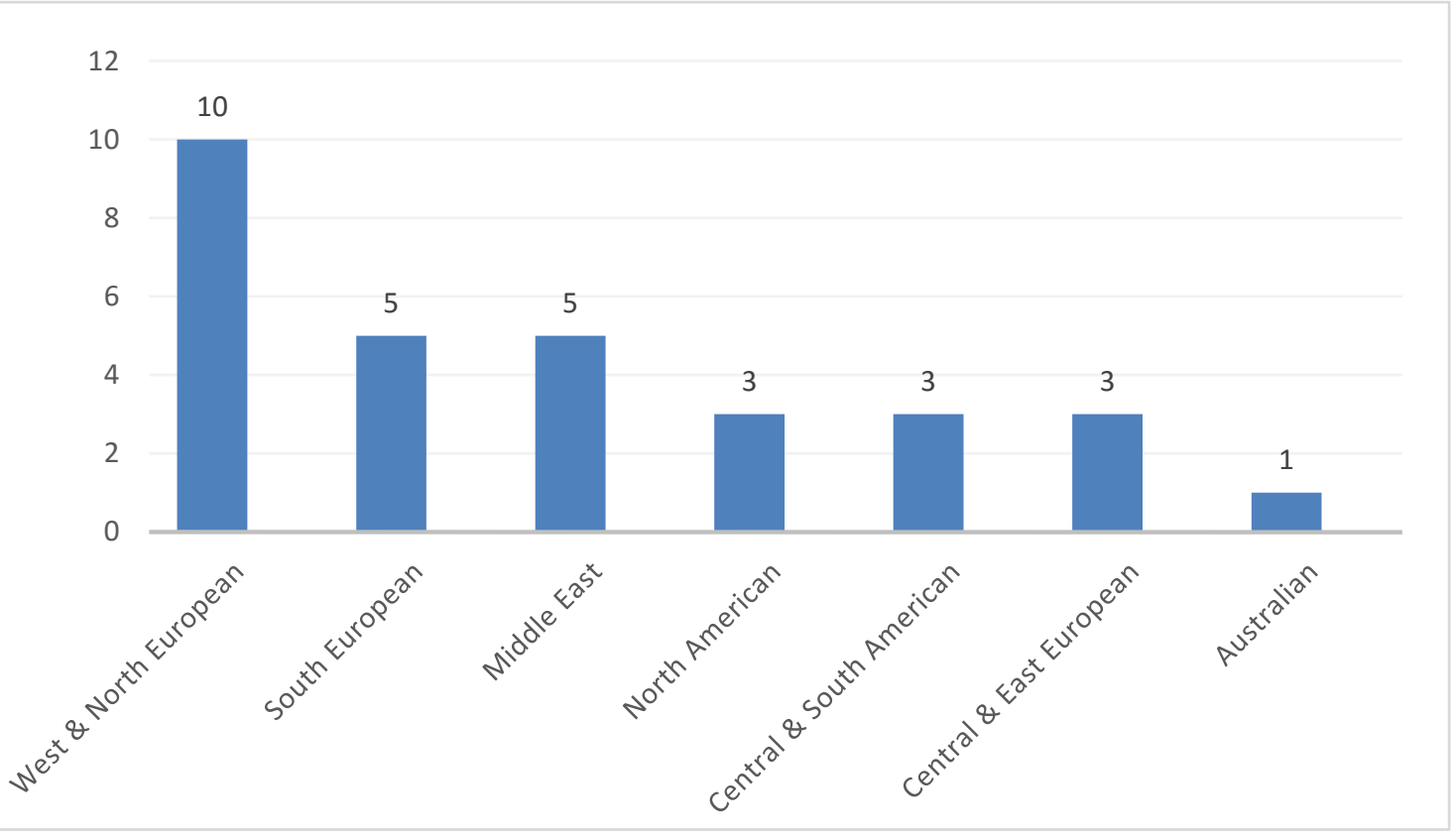

\subsection{Some intermediary observations}

The contemporary fiction is dominated by the circuit of awards for the Spanish language and it is read mainly in English. Europe represents the macro - region with the largest number of high impact, internationally circulation fiction awards.

Also, it is worth mentioning that four macro - regions find themselves completely outside the circuits of the main international fiction awards: Far East, Insular - Indian, North Africa and Sub - Saharian Africa. These four cultural macro - regions in which no international circuits of fiction awards are to be found represent $70 \%$ of world's population and approximately $40 \%$ of world's countries.

One of the most dynamic macro - regions in the hierarchy of prestigious international awards is the Middle East (Israel and the United Arab Emirates). We can realize, by looking at a table of data that the distribution appears to be unequal and it is concentrated solely in the zones of influence of countries with dynamic circulation of English, Spanish and Portuguese. Table 3 illustrates a list of macro - regional cultural corridors, and the frequency of author nomination for the analyzed period $(1980-2015)$ and Table 4 contains a list of authors with more than two nominations, grouped data indicating:

- 30 circuits of international awards;

- 11 cultural corridors of provenance for authors

- 1221 author or title nominations / winners (considering winners and finalists of the 30 circuits of international awards, during $1980-2015)$;

- $\quad$ 880 nominated authors 
Table 3: Total of (internationally awarded) author or title nominations, during $1980-2015$, for the 11 cultural corridors of provenance of authors

\begin{tabular}{lcc}
\hline Corridor & $\begin{array}{c}\text { Frequency of author or title nomination } \\
\text { during } \\
\text { West and North European }\end{array}$ & $\begin{array}{c}\text { Percentage } \\
\text { corridor }\end{array}$ \\
\hline North American & 389 & $31,86 \%$ \\
South European & 190 & $15,56 \%$ \\
Central and South American & 156 & $12,78 \%$ \\
Central and East European & 131 & $10,73 \%$ \\
Australia and New Zealand & 73 & $5,98 \%$ \\
Middle East & 63 & $5,16 \%$ \\
African Sub Saharian & 59 & $4,83 \%$ \\
North African & 52 & $4,26 \%$ \\
Oriental (Pen)insular and Indian & 48 & $3,93 \%$ \\
Far East & 33 & $2,70 \%$ \\
TOTAL & 27 & $2,21 \%$ \\
\hline
\end{tabular}

Table 4: List of authors with more than two nominations in circuits of international awards (68 authors with more than two nominations, i.e a total of 290 out of 1221 nominations)

\begin{tabular}{|c|c|c|c|c|c|}
\hline Name & Country & Frequency & Name & Country & Frequency \\
\hline Margaret Atwood & Canada & 12 & Mario Vargas Llosa & Peru & 6 \\
\hline Ian McEwan & Great Britain & 10 & Orhan Pamuk & Turkey & 6 \\
\hline Peter Carey & Australia & 10 & Sarah Waters & Great Britain & 6 \\
\hline Ali Smith CBE & Scotland & 8 & Doris Lessing & South Africa & 5 \\
\hline Salman Rushdie & Great Britain India & 8 & Haruki Murakami & Japan & 5 \\
\hline Rohinton Mistry & Canada & 7 & Julian Barnes & Great Britain & 5 \\
\hline Colm Toibin & Ireland & 6 & Kazuo Ishiguro & Japan & 5 \\
\hline David Malouf & Australia & 6 & Philip Roth & United States & 5 \\
\hline J. M. Coetzee & South Africa & 6 & William Trevor & Ireland & 5 \\
\hline John Banville & Ireland & 6 & Zadie Smith & Great Britain & 5 \\
\hline Alice Munro & Canada & 4 & Marilynne Robinson & United States & 4 \\
\hline Andrew Miller & Great Britain & 4 & Rose Tremain & Great Britain & 4 \\
\hline Ann Patchett & United States & 4 & Sebastian Barry & Ireland & 4 \\
\hline Anne Tyler & United States & 4 & V. S. Naipaul & TrinidadTobago & 4 \\
\hline Beryl Bainbridge & Great Britain & 4 & Amin Maalouf & Liban & 3 \\
\hline Carol Shields & United States & 4 & Andrea Levy & Great Britain & 3 \\
\hline Hilary Mantel & Great Britain & 4 & Ángeles Caso & Spain & 3 \\
\hline Ismail Kadare & Albania & 4 & Anita Desai & India & 3 \\
\hline James Kelman & Scotland & 4 & António Lobo Antunes & Portugal & 3 \\
\hline Jim Crace & Great Britain & 4 & Antonio Tabucchi & Italy & 3 \\
\hline Barbara Kingsolver & United States & 3 & Gerbrand Bakker & Netherlands & 3 \\
\hline Brian Castro & Australia & 3 & Graham Swift & Great Britain & 3 \\
\hline Carlos Fuentes & Panama & 3 & José Saramago & Portugal & 3 \\
\hline Chimamanda N. Adichie & Nigeria & 3 & Juan Goytisolo & Spain & 3 \\
\hline Damon Galgut & South Africa & 3 & Juan Marse & Spain & 3 \\
\hline David Lodge & Great Britain & 3 & Kate Grenville & Australia & 3 \\
\hline
\end{tabular}




\begin{tabular}{|c|c|c|c|c|c|}
\hline Don DeLillo & United States & 3 & Marie Ndiaye & France & 3 \\
\hline Elena Poniatowska & Mexico & 3 & Michel Houellebecq & France & 3 \\
\hline Fernando S. Dragó & Spain & 3 & Milan Kundera & Czech Republic & 3 \\
\hline Francisco Umbral & Spain & 3 & Octavio Paz & Mexico & 3 \\
\hline Patrick McCabe & Ireland & 3 & & & \\
\hline Per Olov Enquist & Sweden & 3 & & & \\
\hline Per Petterson & Norway & 3 & & & \\
\hline Richard Flanagan & Australia & 3 & & & \\
\hline Tahar Ben Jelloun & Marocco & 3 & & & \\
\hline Timothy Mo & Great Britain & 3 & & & \\
\hline William Boyd & Ghana & 3 & & & \\
\hline Yan Lianke & China & 3 & & & \\
\hline
\end{tabular}

\section{Conclusions on statistical data characteristic to circuits of international fiction awards}

Empirical data concerning authors and titles nominated in the 30 international fiction awards, during $1980-2015$, illustrate the following tendencies:

- Europe is dominating the hierarchy of nominations in the shortlists of finalists for the first 30 international fiction awards;

- However, in the total of over 1200 nominations there are authors from all the cultural macro - regions, although in East and Insular Asia, as well as in Africa, no important international award for fiction is organized;

- In the first tenth of the 880 nominees there are authors coming from all the cultural corridors, resulting in a total of a quarter of the 1221 considered nominations;

- On the 2015 shortlist of finalists for the 30 international awards, there are 60-70 authors as against 35 years ago, when the number was reduced to 10-15 names. An explanation resides in the fact that the number of unrestricted international awards (concerning the authors' country of origin) has risen. Also, there is a far better diversity as to the zones of provenance of the organizing entity, due to the multiplication of intermediary organizations for the circuit of fictional ideas (editors, booksellers, reviewers, critics, bloggers, online stores, etc.);

- Globalization massifies the presence of European and North American authors, but it also makes possible to confer permeability to the international circuit of fictional texts towards all the countries and cultural corridors, with a significant amplification of authors coming from nonexistent countries in the international cultural circuits 50 years ago

- The democratization of fictional texts' circulation has a political component, by being one of the sides of contemporary political speech, a means of formulating the polysemantic from the contemporary power relations;

- Does fiction become political? Does she enter the logic of globalization through the integration of fictional texts' circuit in the globalized speech, as a new discursive area of power relations? If the answer is "yes", at what quantitative level does the fiction's tendency to become political throughout globalization expresses itself?

- 817 authors have been nominated once or twice in the last 35 years as finalists for the international literary awards, as against the 63 authors who were nominated on more than three occasions;

- The 817 authors who have been nominated on one or maximum two occasions in the circuit of international fiction awards, during 1980-2015 come from all the continents 
and from almost 100 countries, as against 63 authors nominated on more than two occasions in the same period;

- Out of the 817 authors, 693 of them have only been nominated once (practically, there is a cohort of approximately 700 authors who have entered the international circuit through this nominations, their speech full of localism, sometimes nationally and culturally gradated entering the logic of a global circulation);

- Are authors becoming political actors through their texts? Does the text become a political speech, intuitively or programmatically? 1980 - 2015 statistics illustrate a high influence of local authors on the globalized literary scene;

- Possible affirmative answers to all the previous questions indicate a new field of interest in the analysis of political sciences. The analysis of text discursiveness describing scenes and political actors is now an established form of understanding contemporary political relations whereas political fictions are qualified as a new field of qualitative political analyse.

\section{References}

Baumann Z. (2005). Globalizarea şi efectele ei sociale. Antet XX Press, Bucureşti.

Berger P. L., Luckman T. (2008). Construirea socială a realităţii. Grupul Editorial Art, Bucureşti.

Bourdieu P. (2013). Limbaj și putere simbolică. Editura Art, Bucureşti.

Bourdieu P. (2012). Regulile artei. Editura Art, Bucureşti.

Bourdieu P. (1986). Economia bunurilor simbolice. Editura Meridiane, Bucureşti.

Foucault M. (2007). Arheologia cunoașterii. Editura RAO, Bucureşti.

Goffman E. (2007). Viața cotidiană ca spectacol. Editura Comunicare.ro, Bucureşti.

Griswold W. (2013). Cultures and Societies in a Changing World. Sage, Chicago.

Houellebecq Michel (2015). Supunere. Humanitas, Bucureşti.

Taylor Charles (2006). Etica autenticităţii. Ideea Design \& Print, Cluj-Napoca.

Political fiction, American History and criticism. Available from: http://www.worldcat.org/. Accessed on 15 Sept. 2015.

International fiction awards. Available from: http://daytonliterarypeaceprize.org/. Accessed on 17 Sept. 2015. International fiction awards. http://en.www.mcu.es/libro/CE/Premios/presentacion.html. Accessed on 17 Sept. 2015.

International fiction awards. http://event.ku.dk/sonning_prize/. Accessed on 17 Sept. 2015.

International fiction awards. http://neustadtprize.org/. Accessed on 17 Sept. 2015.

International fiction awards. http://themanbookerprize.com/. Accessed on 17 Sept. 2015.

International fiction awards. http://themanbookerprize.com/. Accessed on 17 Sept. 2015.

International fiction awards. http://writers.ns.ca/wfns-book-prizes/thomas-head-raddall-atlantic-fictionaward.html. Accessed on 17 Sept. 2015.

International fiction awards. http://www.academie-goncourt.fr/. Accessed on 17 Sept. 2015.

International fiction awards. http://www.alowais.com/. Accessed on 17 Sept. 2015.

International fiction awards. http://www.arabicfiction.org/about-the-prize.html. Accessed on 17 Sept. 2015.

International fiction awards. http://www.celarg.org.ve/Ingles/Premio\%20Romulo\%20Gallegos.htm. Accessed on 17 Sept. 2015.

International fiction awards. http://www.costa.co.uk/costa-book-awards/faqs/. Accessed on 17 Sept. 2015.

International fiction awards. http://www.deutscher-buchpreis.de/archiv/. Accessed on 17 Sept. 2015.

International fiction awards. http://www.dublinliteraryaward.ie/. Accessed on 17 Sept. 2015.

International fiction awards. http://www.fil.com.mx/ingles/i_reco/i_premiofil_fil.asp. Accessed on 17 Sept. 2015.

International fiction awards. http://www.fondation-janmichalski.com/en/prix-jan-michalski/. Accessed on 17 Sept. 2015.

International fiction awards. http://www.franzkafka-soc.cz/cena-franze-kafky/. Accessed on 17 Sept. 2015.

International fiction awards. http://www.independent.co.uk/. Accessed on 17 Sept. 2015.

International fiction awards. http://www.jbookfair.com/en/346-2/. Accessed on 17 Sept. 2015.

International fiction awards. http://www.jewishbookcouncil.org/awards/. Accessed on 17 Sept. 2015.

International fiction awards. http://www.nobelprize.org/nobel_prizes/literature/. Accessed on 17 Sept. 2015.

International fiction awards. http://www.penguinrandomhousegrupoeditorial.com/Novedades/Bases 
XIX_Premio_Alfaguara_2016.pdf. Accessed on 17 Sept. 2015.

International fiction awards. http://www.planetadelibros.com/premios-premio-de-novela-fernando-lara-9.html. Accessed on 17 Sept. 2015.

International fiction awards. http://www.premioplaneta.es/. Accessed on 17 Sept. 2015.

International fiction awards. http://www.premiosaopaulodeliteratura.org.br/. Accessed on 17 Sept. 2015.

International fiction awards. http://www.wheelercentre.com/projects/victorian-premier-s-literary-awards-2015. Accessed on 17 Sept. 2015.

International fiction awards. http://www.womensprizeforfiction.co.uk/. Accessed on 17 Sept. 2015.

International fiction awards. http://zayedaward.ae/. Accessed on 17 Sept. 2015.

International fiction awards. https://www.bn.br/biblioteca-nacional/premios-literarios/premio-camoes. Accessed on 17 Sept. 2015. 